\title{
Research on the Protection for Corporate Intellectual Property of the Belt and Road Initiative
}

\author{
Siqi Wang* \\ School of Arts and Law \\ Wuhan University of Technology \\ Wuhan, P.R.China \\ E-mail:654232845@qq.com
}

\begin{abstract}
In advancing the Belt and Road Initiative, China will adopt a proactive strategy of further opening-up and comprehensively improve the openness of the Chinese economy. Chinese enterprises will face more opportunities and challenges. The Belt and Road initiative involves many countries and regions. The complexity and diversity of the intellectual property environment will inevitably cause many obstacles to the implementation of the intellectual property strategy of enterprises. Therefore, Chinese enterprises should strengthen the protection of intellectual property under the Belt and Road Initiative. This paper firstly analyzes the types of corporate intellectual property risk among countries along the Belt and Road, and then analyzes the reason why the risks take place. At last, this paper offers proposals of the protection of corporate intellectual property from the perspective of the enterprises and government. For enterprises, they should set up more complete risk prevention mechanism and layout of Intellectual Property. For government, they should promote the implementation of national intellectual property strategy and strengthen the dialogue.
\end{abstract}

Keywords-the Belt and Road Initiative; enterprises; intellectual property; risk; intellectual property layout

\section{INTRODUCTION}

In 2013, China put forward major initiative of building the Silk Road Economic Belt and the 21st Century Maritime Silk Road (hereinafter referred to as the Belt and Road Initiative), attracting great attention from the international community. The Belt and Road Initiative is a way for win-win cooperation that promotes common development and prosperity and a road towards peace and friendship by enhancing mutual understanding and trust, and strengthening all-round exchanges The One Belt and One Road initiative jointly built through consultation to meet the interests of all, guided by the spirit of peace and cooperation, openness and inclusive mutual learning and mutual benefit, and the goal of building a community of shared future and interests. [1]It has gradually become the common dream of all peoples along the line. Intellectual property, as an intangible property right and the crystallization of human wisdom, has become an important resource for national development and plays an important role in stimulating innovation, promoting economic development and cultural prosperity. Maintaining close cooperation among countries along the Belt and Road in the field of intellectual property conforms the common interests of all countries and conducive to establishing a sound intellectual property ecosystem and promote the improvement of the intellectual property system in all countries so as to create an environment to innovation and sustainable development.

Statistics show that in 2016, of the 4,834 patent applications submitted by applicants in the countries along the Belt and Road (excluding China) after the first filing of a patent application in China, $85 \%$ of the applicants were Chinese enterprises. In the first half of 2017, China submitted 2,174 patent applications in the countries along the "Belt and Road" (excluding China), up 17.8\% over the same period of last year. [2]This fully reflects that domestic enterprises are actively responding to the Belt and Road Initiative and are focusing on overseas markets Intellectual property layout. The Belt and Road involves more countries and a wide range of regions. Domestic enterprises should make full use of the opportunities for development to promote the" going global "strategy. They should also realize that the intellectual property environment along the route is complex and needs to be taken as precautionary measures. Risk response measures and protection strategy should be formulated as soon as possible, which is particularly important.

\section{The TyPes OF CORPORATE INTELLECTUAL PROPERTY RISKS AMONG COUNTRIES ALONG THE BELT AND ROAD}

\section{A. The Risks of Lacking a Complete Intellectual Property Layout}

Compared with the multinational corporations in developed countries, there is still a certain gap between the awareness of intellectual property layout of Chinese enterprises. Under the strategy of One Belt and One Road, some enterprises in our country lack knowledge of the overseas intellectual property environment and strive to rapidly expand the market and increase sales without paying attention to protecting their own trademarks and patents, neglecting the importance of intellectual property layout .So lost the initiative and even subject to others in the overseas market competition.

Taking a patent layout as an example, the patent layout means that enterprises rely on factors such as comprehensive industries, markets and laws to organically combine patents and construct a rigorous and efficient patent protection network, which eventually forms a patent portfolio favorable to the enterprises. A perfect patent layout can make the protection 
more complete, conducive to dominate the entire technology and market trends, and have a great role in promoting competitiveness of enterprises overseas. [3]As can be seen from the above data, Chinese enterprises have made contributions to improving the level of technological innovation in countries along the Belt and Road, but it should also be noted that the main target countries for filing patent applications by Chinese enterprises are concentrated in a few countries such as India, Russia and Singapore .In most other countries, the number of patent applications and grants is not enough to form a complete patent layout. As the enterprises in developed countries have carried out relatively perfect patent layout in the countries along the Belt and Road, if Chinese enterprises enter the overseas market without the patent layout, they will face a greater risk of infringement of intellectual property rights. For example, in 2014, Beijing Millet Technology Co., Ltd. (Xiaomi) alleges infringement of 8 patents owned by Ericsson and is sued in India by Ericsson to Delhi High Court, India. The temporary injunction Ericsson made to the court included barring Xiaomi from selling in the Indian market and promoting related products suspected of infringing the patents involved in the case. As a result of the temporary injunction finally obtaining the court's support, a number of Xiaomi products were unable to enter the India market for a certain period of time. The inability has had a significant impact on Xiaomi, which is seeking international presence.

\section{B. The Risks of Intellectual Property Policy Differentiation}

Because of the vast strategic scope of the Belt and Road initiative, all countries along the country have great differences in their policies and systems concerning politics, economy, culture and history. [4]In order to seek better economic development, all countries usually adopt intellectual property policies which are more suitable for the development of country's economy and enterprises .For example, in the developed countries in Europe, due to the high level of economic development, enterprises pay attention to the protection of intellectual property and have a sound intellectual property strategy. At the same time, intellectual property legislation and corresponding policies have been perfected and a strict system of judicial and law enforcement of intellectual property have been established. All of these for the country's intellectual property conversion and intellectual property right protection provide a powerful guarantee. If Chinese enterprises enter the market of developed countries, they will greatly increase the risk of infringement of intellectual property if they fail to do such as patent search. In addition, some less developed countries, such as Cambodia and Laos, have still not implemented the Trips Agreement, and intellectual property legislation or policies have not yet been geared to the international conventions. If Chinese enterprises lack knowledge of intellectual property policies and legislation of the related countries before entering overseas markets, they will likely occupy a disadvantageous position in the layout and rights protection of intellectual property and turn proactive to passive.

\section{The Risks of Intellectual Property Trade Barriers}

Normally, it is difficult for people to link up intellectual property rights and barriers. When the exclusivity of intellectual property is applied to multinational production and operation, a country's intellectual property protection policy is linked with import and export trade. As a result, it has become one of the most important trade policies in countries and then created intellectual property trade barrier. In recent years, some countries and enterprises along the Belt and Road have the phenomenon of building a non-tariff trade barrier with intellectual property as the core, setting obstacles for Chinese enterprises to enter overseas markets. Such barriers are sometimes constructed separately by patents, trademarks, copyrights and other intellectual property rights, and in more cases are combined with technical standards, safety standards and environmental protection standards, forcing us to pay high costs and price to successfully enter the market. [5]Due to the imbalance between economic development and technological development in different countries, the developed countries use their own powerful advantages to formulate a series of technical standards and set a series of barriers. In other countries, in order to develop high and new technologies, they always have to pay high royalties, which not only restrict the circulation of technology, but also restrict the development of related technologies. Some countries have also taken protective measures such as export restrictions, import licenses, technical trade barriers and green trade barriers to China while promoting their own research and development capabilities, and at same time hindered the development of overseas markets for Chinese enterprises.

\section{THE STRATEGY FOR CORPORATE INTELLECTUAL} Property Protection Of THE Belt AND RoAd Initiative

As China continues to implement the strategy of the Belt and Road, the pace of Chinese enterprises entering overseas markets is accelerating. Government departments and enterprises should play their respective advantages and improve the layout of intellectual property in overseas markets so as to better protect intellectual property rights and promote the trade of Chinese enterprises in the countries along the Belt and Road.

\section{A. Protection Strategy of Corporate Intellectual Property at the Enterprise Perspective}

1) Construct Complete Intellectual Property Risk Prevention Mechanism and Protection System

Chinese enterprises should raise their intellectual property strategy to the height of business competition strategy and make full use of the technical means such as patent early warning and competitive intelligence analysis to establish a complete intellectual property risk prevention mechanism and intellectual property protection system. During the implementation of the Belt and Road Initiative, Chinese enterprises inevitably face the risk of infringement. In order to resolve the risks, it is necessary to track, assess and pre-analyze the intellectual property in advance. [6]They also should grasp the overseas market and our country's intellectual property policies and relevant legislation, and learn to use judicial 
means and negotiation strategies to resolve the risks when faced with the difficulties.

\section{2) Carry out More Complete Layout of Intellectual} Property

In the strategic process of going global, Chinese enterprises should focus on core technologies and carry out more complete intellectual property layout. Taking the patent layout as an example, in the course of participating in the international competition, enterprises should carry out the patent layout for its own core technologies. In addition, they are also supposed to implement the layout of peripheral and defensive patents. They will gradually occupy the overseas technology markets through patent distribution to enhance their competitiveness, defend their patent rights and curb patent infringement in the cradle. At the same time, conducting patent intelligence analysis, mining industry information hidden behind the patent data, using patent navigation to make patent layout are magic weapons for enterprises to win in the technology market. Through promoting the layout of intellectual property and focusing on the development of competitive enterprises, Chinese enterprises can remain invincible in overseas markets competition.

\section{B. Protection Strategy of Corporate Intellectual Property at Government Perspective}

1) Promote the Implementation of National Intellectual Property Strategy

Through the implementation of the national intellectual property strategy, the government should gradually resolve the global, institutional and policy issues in international trade, and created a sound system and market environment for the international trade of enterprises and other micro-organizations. Relevant government departments in China should fully coordinate. First of all government should encourage enterprises to actively apply for intellectual property overseas. Second, they should build information bases of intellectual property, cultivate intellectual property personnel, provide subsidies and tax preference. At the same time, our government departments should take the initiative to provide better public policy services for enterprises, and actively promote the strategic layout of intellectual property rights for Chinese enterprises in overseas markets. Taking patent applications as an example, filing patent applications through the Patent Cooperation Treaty (PCT) is the main way for Chinese enterprises to carry out patent layout in the countries along the Belt and Road. However, the application procedures are complex and the period is long. It is suggested that Chinese patent administration departments should make full use of such tools as patent examination expressways and bilateral agreements to facilitate the enterprises in carrying out the patent layout in countries along the Belt and Road.

\section{2) Intellectual Property Dialogues among Countries along} the Belt and Road.

Under the background of globalization, the domestic legislation on intellectual property and related policies will be affected and restricted by international treaties. Our government ought to actively promote the intellectual property dialogue among all countries in the region along the Belt and Road and enhance mutual understanding and coordination of intellectual property conflicts through bilateral or multilateral dialogues so as to reduce the losses caused by intellectual property conflicts .Government should gradually establish mutual respect, peaceful coexistence of the intellectual property environment. In response to the disputes over intellectual property rights that Chinese enterprises are encountering in the countries along the "One Belt and One Road", our government departments can pilot the construction of overseas fast rights protection centers in close economic and trade area, which can help Chinese enterprises quickly use legal arms to safeguard their own interests in case of intellectual property litigation.

\section{CONCLUSION}

Under the Belt and Road initiative, we should be openminded and commit ourselves to safeguarding the global free trade system and the open-world economy. Although Chinese enterprises may face intellectual property risks in overseas competition, they also provide a good opportunity for Chinese enterprises to carry out intellectual property strategic layout in the countries along the Belt and Road. Intellectual property should be an integral part of the strategy of the Belt and Road. In the process of making the country powerful by intellectual property strategy, realize the organic unity of the Chinese Dream and the World Dream.

\section{REFERENCES}

[1] Jiao Jie, The Joint of Two Major Strategies: Intellectual Property Strategy and China 's "Going Global" Strategy, Tsinghua University newspaper,2008(2) .(In Chinese)

[2] Cai Zhonghua, How to go further in the Belt and Road? , People’s Daily Online, 2017-08-03. (In Chinese)

[3] Fang Liyu, Research on Early Warning and Management Mechanism for Intellectual Property Risk of One Belt and One Road Strategy, Science and Technology Management Research,2016(8).(In Chinese)

[4] BALDIA S, Intellectual Property in Global Souring: the Art of the Transfer [J],Georgetown Journal of Intellectual Law,2007,38(3)

[5] The National Development and Reform Commission, Ministry of Foreign Affairs and Ministry of Commerce, Promote the vision and action of building the Silk Road Economic Belt and the 21st Century Maritime Silk Road, 2015.(In Chinese)

[6] Zhang Zhanjiang, Strategy of Intellectual Property Protection under the Belt and Road Strategy, Patent Examination Practice \& Research, 2015(6). (In Chinese) 